\title{
臨床報告小児例における瘻孔閉鎖を目標とした 十全大補湯の使用経験
}

\author{
千葉 庸夫 \\ Nine Clinical Case Studies using Juzen-taiho-to for \\ the Closure of Fistulae in Children
}

\section{Tsuneo CHIBA}

M. D., Department of Pediatric Surgery, National Sendai Hospital, 2-8-8 Miyagino, Miyagino-ku Sendai 983, Japan

\begin{abstract}
Post-inflammatory or post-operative fistula formation is a troublesome complication. As these fistulae are not amenable to closure, surgical excision is usually indicated afterwards. In order to close these fistulae, Juzen-taiho-to was administered to nine children. The location of these fistulae were: cervical region in 1 patient, abdominal wall in 4 patients and external genitalia (perineum) in 4 patients. The fistulae located in the cervical and abdominal regions closed within three weeks of administration, and those located in the external genitalia within six months, including anal fistula. These results suggest the applicability of Juzen-taiho-to for fistula closure.
\end{abstract}

Key words: fistula, Juzen-taiho-to, Astragali Radix

Nihon Toyo Igaku Zasshi (Japanese Journal of Oriental Medicine), 46, 427-431, 1995 (accepted May 1, 1995)

\section{緒 言}

瘦孔は先天性のものを除けば炎症性疾患や各種 手術後に発生する合併症であり，難治性で，長期 間にわたる処置の後に結局は手術的切除を余義な くされることが多く，それでもまた再発する例が みられるのが現状である。われわれは以前に成人 例に拈いて瘻孔を形成した数例に気血双補の十全 大補湯（TJ-48）を用いて良好な結果を得た経 験 を有して扣り，小児に拈ける瘦孔にも有用ではな
いかと考え，その検討を行ったので報告する。

\section{対象および方法}

国立仙台病院小児外科に预いて治療した例のう ち瘦孔を形成した 9 例を対象として通常の創傷処 置を施行しながら十全大補湯（TJ-48）を服用さ せ創の閉鎖状況について検討した。対象とした瘦 孔はいずれも通常は難治性であり，いずれは手術 的処置が必要と考えられたものである。年長例で は証を考慮したがいずれも術後あるいは炎症後の

医，国立仙台病院小児外科，宮城，干983 仙台市宮城野区宮城野2-8-8

[1995年 5 月 1 日受理 $]$ 
表 1 原疾患特よび使用漠方剂

\begin{tabular}{|c|c|c|c|c|}
\hline 症例 & 年齢 & 性 & 原疾患 & 漢方剂 \\
\hline 1 & 6 歳 & 男 & 正中頸需胞 & 十全*1, 黄者*2 \\
\hline 2 & 7 歳 & 男 & $\begin{array}{l}\text { 外傷性肝, } \\
\text { 腎破裂 }\end{array}$ & 十全, 大建*3 \\
\hline 3 & 4 歳 & 男 & $\begin{array}{l}\text { 尿莫管瘻 } \\
\text { (感染性) }\end{array}$ & 十全, 紫雲亳 \\
\hline 4 & 7 歳 & 男 & 穿孔性虫垂炎 & 十全, 大建 \\
\hline 5 & 15歳 & 女 & $\begin{array}{l}\text { 骨盤脂肪織炎, } \\
\text { 膿瘍 }\end{array}$ & 十全 \\
\hline 6 & 5 月 & 男 & 痔瘻 & 十全 \\
\hline 7 & 3 月 & 男 & $\begin{array}{l}\text { 直腸会陰瘻, } \\
\text { 鎖肛 }\end{array}$ & 十全 \\
\hline 8 & 1 月 & 女 & $\begin{array}{l}\text { 直腸会陰瘦, } \\
\text { 鎖肛 }\end{array}$ & 十全 \\
\hline & & & $\begin{array}{l}\text { Perineal } \\
\text { canal }\end{array}$ & \\
\hline 9 & 6 歳 & 男 & 痔瘻 & 十全 \\
\hline
\end{tabular}

$* 1$ 十全大補湯 $* 2$ 黄者建中湯 $* 3$ 大建中湯

瘦孔であり，小児であること，表に関係している ことなどから各症例間の差はとれ汪ど無いと考觉 られ, また瘦孔の形成には抵抗力の減退（免疫力 低下), 栄養不良, 先天性のものでは虚弱性, 術 後や炎症後のものでは局所の虚弱性, 衰弱, 疲労 といった気虚の要因が関与すると共に組織での出 血や循環不足（閉鎖機転の妨害）といった血虚の 要因が関与して拈り, 瘦孔治療には気血双補の薬 剂が有用と考光られ，われわれの成人例での経験 とこれまでの報告1) 3)を参考に十全大補湯を投与 した。投与量は体重に応じて決定し，すべて経口 的に服用させた。これらの例に执いて瘦孔閉鎖の 有無和よび閉鎖までの期間を検討した。なお，十 全大補湯の投与期間は瘦孔閉鎖までを原則とした が，一部の例では状態によって短縮あるいは長期 間の服薬を指導した。

\section{結 果}

表 1 に対象例の概要を示す。年齢は生後 1 カ月 から15歳に及び, 男児 7 例, 女児 2 例である。原 疾患は外傷, 炎症性疾患, 先天性疾患など種々な ものが含まれている。これらはいずれも瘦孔を形 成した例であるが，このうち手術後の瘻孔形成例 は症例 $1 \sim 5$ (症例 5 飞ついては後述) で, 先天
表 2 㾞閉鎖までの期間

\begin{tabular}{|c|c|c|c|c|}
\hline \multicolumn{2}{|c|}{ 瘻孔などの部位 } & \multicolumn{2}{|c|}{$\begin{array}{l}\text { 黄者剂の } \\
1 \text { 日投与量 }\end{array}$} & \multirow{2}{*}{$\begin{array}{c}\begin{array}{c}\text { 閉鎖委で } \\
\text { 期間 }\end{array} \\
17 \text { 日 }\end{array}$} \\
\hline 1 & 頸部 & 十全*1 & $\begin{array}{l}2.5 \mathrm{~g}, \\
\text { 黄耆*2 } 6 \mathrm{~g}\end{array}$ & \\
\hline 2 & 腹部（胆汁瘦） & 十全 & $\begin{array}{l}5 \mathrm{~g} \\
\text { (7日間投与) }\end{array}$ & 14日 \\
\hline 3 & 臍部 & 十全 & $2.5 \mathrm{~g}$ & 7 日 \\
\hline 4 & 回盲部 & 十全 & $5 \mathrm{~g}$ & 7 日 \\
\hline 5 & 左鼠径部 & 十全 & $7.5 \mathrm{~g}$ & 14日 \\
\hline 6 & 肛門周囲 & 十全 & $2.5 \mathrm{~g}$ & 3 月 \\
\hline 7 & 会陰部 & 十全 & $2.5 \mathrm{~g}$ & 1. 5月 \\
\hline 8 & 会院部 & 十全 & $2.5 \mathrm{~g}$ & 1 月 \\
\hline 9 & 肛門周团 & 十全 & $5 \mathrm{~g}$ & 6 月 \\
\hline
\end{tabular}

性㾇孔は症例 7,8 , 炎症後の瘦孔は痔 瘻の 例 （症例 9 については後述）である。十全大補湯は 全例に投与したが，その他の漢方剂として一時的 腸管通過障害がみられた 2 例に大建中湯，感染創 の治療を目的として紫雲亳を塗布した例が 1 例， 先に黄者建中湯を使用した例が 1 例ある。

表 2 は瘦孔の部位敊よび瘦孔閉鎖までの期間を 示す。瘦孔の部位は頸部が 1 例, 腹部が 4 例, 会 陰部周辺が 4 例である。症例 1 〜 5 は手術後であ れば本来は瘦孔の形成はみられないものであり主 として漿液性の異常な分泌（1 例は胆汁）が排泄 されて扣り, 症例 7,8 では鎖肛の手術後は閉鎖 されるものであるが開通したま屯残った例であ る。十全大補湯の投与量は $2.5 \mathrm{~g} \sim 7.5 \mathrm{~g}$ で体重抒 よび程度により決定した。十全大補湯は食前に微 温湯で服用させたが飲みにくい場合はドリンクヨ ーグルトで服用させた。瘦孔の閉鎖なでに要した 期間は 1 週間から 6 カ月に及んでいるがその傾向 は大きく 2 つに分けることができる。頸部や腹部 の瘦孔では閉鎖までに要した期間は使用後 7 日か ら17日であったが，肛門部を含む会陰部周辺では 比較的長期間の服用が必要であり，1 月 $~ 6$ カ 月を要した。現在各例とも最短で 1 年以上を経過 して和り, 再発例はみられない。

以上の内, 2 症例について概要を述べる。

症例 $5: 15$ 歳女。平成 5 年10月初旬より腰痛を 


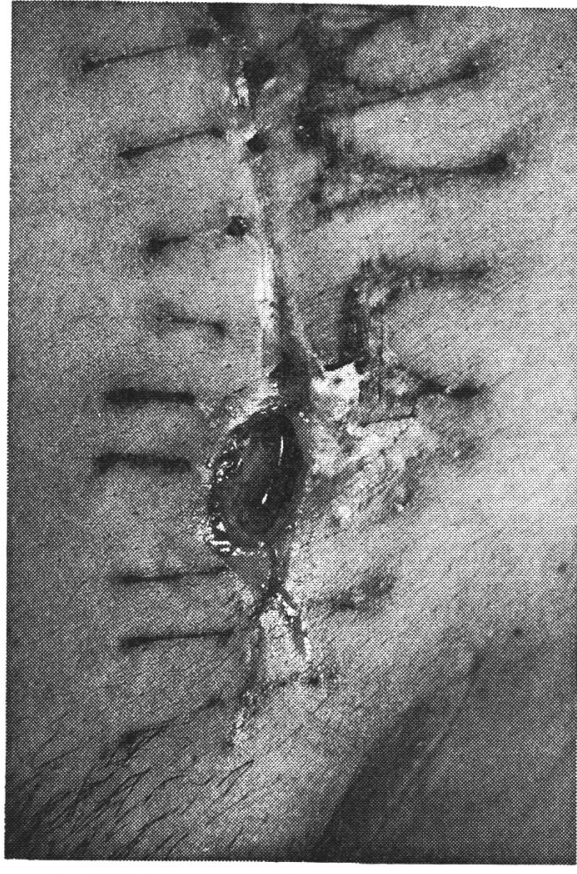

図 1 骨盤脂肪織炎後の皮膚瘻孔

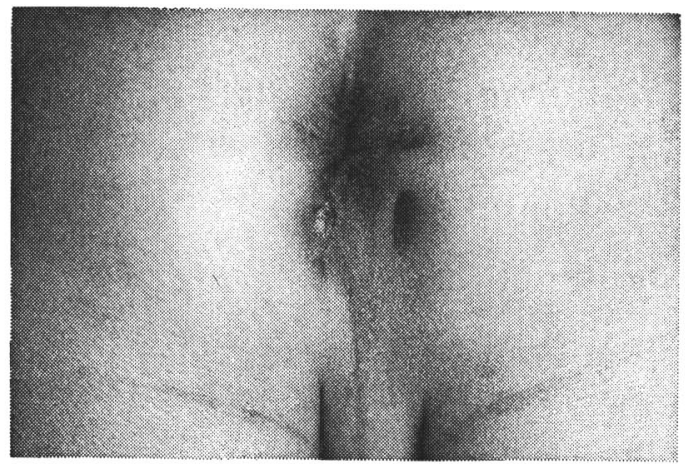

図 3 難治性痔瘦に対して十全大補湯を使用し 完全閉鎖がみられた例

瘢痕化した切開部が肍門周囲にみられる。

訴え近医で腰椎牽引を受けていたが疼痛はとれず 歩行困難となった。その頃より $38^{\circ} \sim 39^{\circ}$ の発熱が みられるようになり CT 検査にて骨盤腔内に異常 陰影が認められ同年10月21日手術を受けた。開腹 時硬い腫瘤が触知されたため悪性リンパ腫を疑わ れ，当科に転院した。

しかし組織所見では悪性腫痬ではなく脂肪織炎

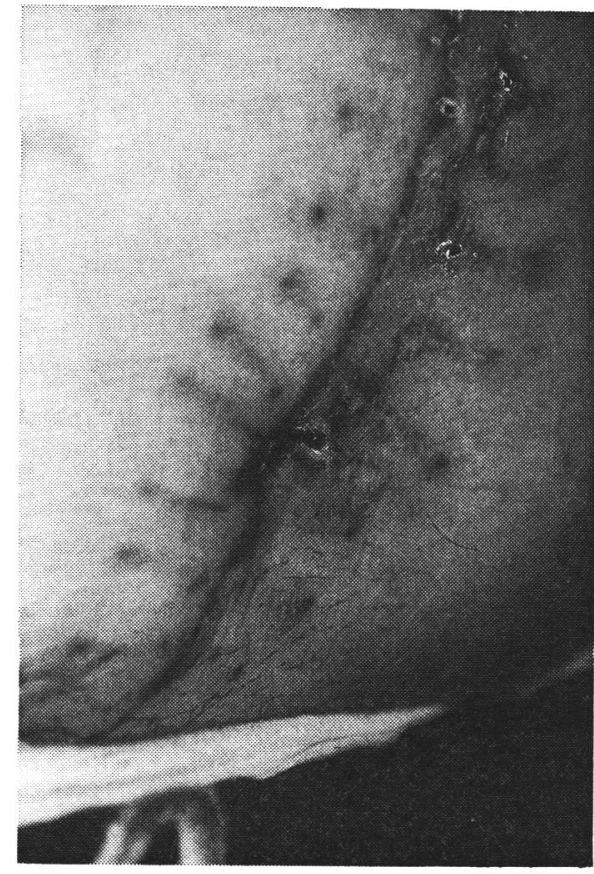

図 2 図 1 と同一例の十全大補湯使用後の創部 すでに瘦孔が閉鎖している。

であったため抗生剤のみで治療していたが相変ら ず歩行が困難であった。11月になって瘦孔が生じ

(図 1), さらさらした透明の液が多量排出され るようになり，日毎に増量したため十全大補湯の 適応と判断し (舌は淡白, 脈は沈), 1 日 $7.5 \mathrm{~g}$ を 服用させた。

その結果日増しに体力が回復し, 瘦孔よりの排 液量が減少し, 瘦孔が縮小し 2 週間で閉鎖した (図 2)。服薬後19日目より歩行が可能となり,CT 像でも腫瘤陰影の縮小がみられたため十全大補湯 を12月末日まで服用させた。平成 6 年での CT 像 では腫瘤はみられなくなり, 歩行他学校生活上も 特に問題がなく現在に至っている。

症例 $9: 6$ 歳男。生後 9 日, 肛門周囲膿瘍のた め切開を受けたが，その後しばしば排膿を繰り返 し痔瘦となった。その後も全く治癒する傾向はみ られず平成 5 年 (6 歳) になって漢方薬治療を求 めて当科を受診した。体格は中等度であったが長 期間治療を繰り返し病勢に対しては負けているも のと判断し, 十全大補湯を 1 日 $5 \mathrm{~g}$ の割合で投与 
した。投与後は瘻孔からの排液量特よび排膿の回 数が減少し，次第にその間隔が延び，6力月後に は排膿がみられなくなり（図３），半年経過した 現在も再発はみられない。

\section{考 察}

瘦孔は種々な炎症性疾患の後や手術後に形成さ れる難治性の病巣で，種々な部位に形成され，長 期間の治療を要し，多くの場合は手術的に切除す る必要がある。現在では少なくなった結核性の瘦 孔や骨髄炎などによる㿉孔を含めて古来どのよう な治療が行われていたかは興味のもたれるところ である。これらの治療法の中には有効なものも含 まれていたと思われ，これらを応用することによ り西洋医学に頼るあまり手術を急ぎ，再び瘦孔を 形成したり，部位の問題や原疾患の問題，あるい は全身状態の問題から手術が不可能な場合汇治療 効果を上げることができるものと期待される。今 回われわれは種々な東洋医学的手法のらち漢方剂 の効果を検討すべく補気補血の効果のある十全大 補湯を用いて検討した。われわれは日常の診療に 扣いて乳癌手術後の手術創でのリンパ瘦, 膵癌術 後の脺液瘦など数例で十全大補湯が効果的であっ たことを経験していたので，今回は小児例のよう に実証と思われる例に括ける有用性について検討 した。

㾇孔に対して使用される漢方㓮としては千金内 托散 (内補散) ${ }^{112)}$, 十全大補湯 ${ }^{13}{ }^{3)}$, 括よび黄者 建中湯4）5などがあり，臨床例での報告例では千 金内托散を虫垂炎後の瘦孔例やカリエスの膿痬排 出不良(例67) とか腸閉塞手術後の瘦孔形成例飞 ${ }^{3)}$, 十全大補湯を寒性膿痬例 ${ }^{8)}$ や痔㾞 ${ }^{9}$ に，また黄者 建中湯では虚弱児のるいれき例や瘦孔例10)などが ある。痔㿉ではその他, 帰者建中湯, 帰脾湯, 当

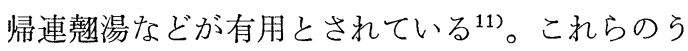
ちエキス剤など製剤となって市販されているもの は十全大補湯, 黄者建中湯, 帰者建中湯, 帰脾湯 などである。これらに共通に含るれる生薬黄者は マメ科のキバナオウギやナイモウオウギなどの根 であり，その働きの中に補気や消腫のほかに托創 生肌作用がみられる。これは潰痬や㾞孔の治癒,
浸出創や創口の茨愈合不全の治癒, 排膿不良例の改 善などをもたらし，本た当帰，川芦，白术，人 参, 肉桂などと用いるとさらに効果が増すので前 述の各製剂は瘻孔の治療に適していると言える。

われわれは瘦孔の病態を考慮すると気虚のみな らず血虚（特に局所）をも補ら必要があると考兄 十全大補湯を使用した。本方剤は黄者, 桂枝, 地 黄, 药薬, 川芎, 当帰, 人参, 获苓, 甘草, 蒼术 からなる気血双補の製剂で補血の四物湯と補気の 四君子湯をあわせた八珍湯に黄者，桂枝を加えた もので,一般には術後の体力低下, 疲労倦怠, 食 欲不振，寝汗，貧血などに使用されるが，外科的 には術後の回復を計る目的のみならず抗癌剤の副 作用の軽減を目的として使用することが多い。本 方剂には前述した黄者や人参など創傷治療に有効 な生薬が多く含まれて和り, びらん, 潰痬, 瘦孔 などにも積極的に使用すべきであると思われる。 本報告で得られた知見では頸部や腹部の瘦孔では 使用後 $1 \sim 3$ 週で治瘉するのに対し, 会陰部, 肛 門部の瘦孔（痔瘻を含む）では $1 \sim 6$ カ月間の服 用が必要である。それゆ光服用の目安としては腹 部以上の部位の瘦孔に対しては 3 週間, 痔瘻々の 他の会陰部の瘦孔例では 6 カ月間とし，服用の継 続か手術を行うかの選択をすることが望ましいと 思われる。

\section{結 論}

瘦孔はひとたび形成されると難治性のものが多 いが，われわれは小児例の瘻孔 9 例に対して十全 大補湯を使用し，良好な結果を得た。頸部や腹部 では 7 17日の使用で瘦孔の閉鎖をみ，会陰部や 肚門部（痔瘦など）では $1 \sim 6$ カ月の服用で閉鎖 した。これらの例の多くのものは本来，手術とな る可能性のある㾞孔であり, 気血双補の十全大補 湯が瘦孔の修復にきわめて有効であることが判明 した。瘦孔は通常は全身状態や局所の状態が不良 または虚の状態に和こり，手術が困難な場合もあ る。このよらな場合に本方剤の様に体の状態を改 善させながら瘻孔も治療できるという生体にとっ て望ましい結果が得られたことから瘦孔の治療に あたっては手術を考虑する以前に本方剂を使用す 
ることが望ましいと思われる。

\section{文 献}

1）松田邦夫 : 癱疽, 万病回春解説, 創元社, pp.896 $-897,1990$

2 ) 浅田宗伯 : 内補散, 勿誤薬室方亟口訣, 津村順天 堂, p.205, 1981

3 ) 矢数道明: 十全大補湯, 臨床応用漢方処方解説, 創元社, pp.258-262, 1991

4) 矢数道明：小建中湯, 臨床応用漢方処方解説, 創 元社, pp.285-291, 1991

5 ）大塚敬節：黄者建中湯の覚光書, 漢方診療三十年 一治験例を主とした治療の実際，創元社，pp.9798, 1980

6 ）矢数道明：千金内托散，臨床応用漢方処方解説,
創元社, pp.358-361，1991

7 ) 大塚敬節 : 虫垂炎手術後, 瘡口から膿の出る患 者, 漢方診療三十年一治験例を主とした治療の実 際, 創元社, p.368, 1980

8 ）大塚敬節 : 寒性膿瘍のある股関節結核, 漢方診療 三十年一治験例を主とした治療の実際，創元社， pp.329-330, 1980

9 ）大塚恭男：十全大補湯一臨床(1), 漢方製剤 の 知 識 $(V)$ ，薬事新報社，pp.176-179，1988

10）大塚敬節：虚弱児童のるい永き，漢方診療三十 年一治験例を主とした治療の実際, 創元社, pp.96-97, 1980

11）大塚敬節 : 外科疾患一疛瘻, 漢方診療医典, 大塚 敬節, 矢数道明, 清水藤太郎著, 南山堂, p.206, 1990

要旨 瘦孔は炎症性疾患や手術後にみられる難治性の合併症であり，全身状態が不良であっ たり局所の状態の問題から治療には長期間を要し，結局は手術が必要となる事が多い。しかし 瘦孔に対して漢方剂で治療し良好な結果が得られている報告がみられることから，われわれは 小児の瘦孔形成例 9 例に対して気血双補の十全大補湯を使用しその効果を検討した。その結 果，頸部や腹部の瘻孔では使用後 17 日以内で瘦孔が閉鎖，会陰部附近では痔瘦も含め 6 カ月以 内に閉鎖した。本方剂は成人例でも多くの瘦孔に有効であり，外科では手術後の瘦孔に積極的 に使用すべきであると思われた。

キーワード : 瘻孔, 十全大補湯, 黄老 